\title{
KONSOLIDASI KAPITAL SOSIALPEMULUNG SAMPAH TEMPAT PEMBUANGAN AKHIR SAMPAH KARANGREJO KOTA METRO
}

\author{
Ahmad Madkur \\ Institut Agama Islam Negeri Metro \\ Jalan Ki Hajar Dewantara 15A Kota Metro, 34124, Lampung \\ E-mail:madzkurahmad@gmail.com \\ Suhendi \\ Institut Agama Islam Negeri Metro \\ Jalan Ki Hajar Dewantara 15A Kota Metro, 34124, Lampung \\ E-mail: hends9000@gmail.com \\ Muhamad Nasrudin \\ Institut Agama Islam Negeri Metro \\ Jalan Ki Hajar Dewantara 15A Kota Metro, 34124, Lampung \\ E-mail: idenasrudin@gmail.com
}

\begin{tabular}{c|c|c}
\hline Received: & Revised: & Approved: \\
$21 / 08 / 2017$ & $27 / 11 / 2017$ & $04 / 12 / 2017$ \\
\hline
\end{tabular}

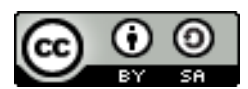

Konsolidasi Kapital Sosial Pemulung Sampah Tempat Pembuangan Akhir

Sampah Karangrejo Kota Metro is licensed under a Creative Commons

Attribution-ShareAlike 4.0 International License.

\begin{abstract}
Abstrak
Pemulung sampah adalah warga yang terpinggirkan dalam peta ekonomi, sosial, dan politik. Lalu bagaimana upaya mereka agar bisa merangsek ke tengah peta? Tulisan ini mengulas bagaimana para pemulung sampah di TPAS Karangrejo Kota Metro mengonsolidasi kapital sosial bersama para stakeholders terkait, termasuk dosen IAIN Metro, Walhi, perusahaan, dan Pemerintah Daerah. Tulisan ini bersumber dari kegiatan PAR (participatory action research) yang merupakan sebuah kegiatan pengabdian dan penelitian yang dilakukan oleh dosen IAIN Metro kepada
\end{abstract}


warga pemulung anggota sebuah paguyuban di TPAS Karangrejo. Potret yang dideskripsikan meliputi bagaimana mereka mengorganisir diri, menciptakan alat-alat produksi, lalu meningkatkan nilai tambah atas produk-produk mereka. Tujuannya adalah bagaimana mereka berdaya di hadapan rentenir sekaligus meningkatkan taraf hidup. Ujung tulisan ini mengupas sejauh apa mereka berdaya, juga apa peluang dan tantangan yang mereka hadapi.

Kata kunci: Kapital Sosial, Pemulung Sampah, dan TPAS Karangrejo.

\section{Abstract}

Waste pickers are frequently marginalized in economic, social, and political maps. So how do they try to get to the center of the map? This research-based paper reviews how waste pickers in TPAS Karangrejo Metro City consolidate their social capital with relevant stakeholders, including the lecturers of State Islamic Institute (IAIN) Metro, WALHI, companies, and local government. The writing of this paper is based on participatory action research in which the community empowerment and research were both conducted in the same time by a lecturers team of IAIN Metro for the waste pickers in TPAS Karangrejo. The portraits described include how they organize themselves, create the means of production, and then increase the added value of their products. The goal is how they are empowered in the presence of moneylenders while improving living standards. The end of this paper explores how far they are empowered, and what opportunities and challenges they face.

Keywords: Social Capital, Waste Pickers, TPAS Karangrejo

\section{A. Pendahuluan}

Sebagai warga yang terpinggirkan, tak banyak modal yang dimiliki oleh pemulung sampah. Mereka tidak memiliki akses kepada sumber modal ekonomi maupun modal kultural. Meskipun demikian, mereka masih memiliki satu modal yang inheren ada bersama mereka, yakni modal sosial yang bisa dijadikan sebagai batu loncatan untuk memberdayakan diri meningkatkan taraf hidup. ${ }^{1}$

Dalam makalahnya, The Forms of Capital, sosiolog Pierre Bourdieumembagi modal ke dalam tiga jenis: modal ekonomi, modal kultural, dan modal sosial. Modal sosial ia definisikan sebagai

${ }^{1}$ Rusydi Syahra, “Modal Sosial: Konsep dan Aplikasi," Jurnal Masyarakat dan Budaya 5, no. 1 (2003): 1-22. 
kumpulan sumber daya, baik yang aktual maupun potensial, yang melekat pada jejaring atau keanggotaan dari sebuah kelompok atau komunitas yang didasarkan oleh adanya sikap saling kenal dan saling mengakui; yang memungkinkan para anggotanya untuk memanfaatkan modal-milik-kolektif tersebut. ${ }^{2}$

Mengacu pada definisi Bourdieu tersebut, tulisan ini mencoba melihat apa dan bagaimana sumber daya yang dimiliki oleh para pemulung sampah di TPAS Karangrejo Kota Metro, baik yang potensial ataupun yang aktual. Lebih awal, bagaimana jejaring tersebut dibangun dan dipupuk. Karena melihat sejarahnya, terdapat lebih dari 100 orang pemulung yang bekerja hampir setiap hari dengan penghasilan yang jauh di bawah nilai wajar.

Lebih lanjut, tulisan ini akan mengkaji bagaimana para pemulung tersebut mengakumulasi kapital sosial, kemudian mengonsolidasikan kapital sosial dengan para pihak yang terkait. Kemudian, bagaimana para pemulung tadi mengonversi kapitalnya menjadi kapital ekonomi dan kapital kultural, juga kapital simbolik.

Dalam ruang yang lebih luas, kajian ini berupaya menerjemahkan fungsi sosial sebagaimana disinggung Coleman dalam Portes sebagai wujud lain dari dua elemen penting dalam kehidupan sosial, yakni struktur sosial dan bagaimana para aktor bermain dalam struktur tersebut. Dalam pemahamannya, kapital sosial memungkinkan setiap aktor dalam sebuah komunitas membangkitkan power yang bersumber dari relasi, timbal-balik, kepercayaan, dan nilai-nilai sosial yang dianut. ${ }^{3}$

Secara lebih lanjut, tulisan ini mengupas siapa saja aktor yang terlibat dalam TPAS Karangrejo dan struktur sosialnya. Bagaimana para pihak membangun sikap saling percaya di antara mereka; apa imbal-balik yang diserah-terimakan para aktor di dalamnya; juga bagaimana nilai-nilai sosial yang dihidupi dalam lingkungan sosial dijalani dan saling bertukar pengaruh dengan kepentingan para pemulung.

${ }^{2}$ Pierre Bourdieu, "The Forms of Capital," 1986, https:/ /www.marxists.org/ reference/subject/philosophy/works/fr/bourdieu-forms-capital.htm\#n11; Syahra, "Modal sosial."

${ }^{3}$ Alejandro Portes, "Social Capital: Its Origins and Applications in Modern Sociology," Annual review of sociology 24, no. 1 (1998): 1-24. 
Tulisan ini menggunakan paradigma konstruktivisme dengan pola participatory community empowerment.Tim penulis terlibat langsung dalam proses konsolidasi kapital sosial para pemulung sebagai salah satu katalisator. Meski demikian, tulisan ini diupayakan agar bisa objektif semaksimal mungkin.

Terkait kebaruan data, sejauh pengamatan tim penulis memang sudah banyak peneliti yang mengkaji peran modal sosial dalam pemberdayaan masyarakat, di antaranya adalah Pranadji ${ }^{4}$, Suharjito dan Saputro ${ }^{5}$, Pontoh ${ }^{6}$, Thobias ${ }^{7}$, Nasution $^{8}$, Widodo ${ }^{9}$, dan Susanto $^{10}$. Namun demikian, belum ada kajian yang secara spesifik mengkaji konsolidasi kapital sosial di kalangan pemulung sampah di TPAS Karangrejo Kota Metro, Lampung.

${ }^{4}$ Tri Pranadji, “Penguatan Modal Sosial Untuk Pemberdayaan Masyarakat Pedesaan dalam Pengelolaan Agroekosistem Lahan Kering (Studi Kasus di Desadesa (Hulu DAS) Ex Proyek Bangun Desa, Kabupaten Gunungkidul dan Ex Proyek Pertanian Lahan Kering, Kabupaten Boyolali)," Jurnal Agro Ekonomi 24, no. 2 (2016): 178-206.

${ }^{5}$ Didik Suharjito dan Gunanto Eko Saputro, “Modal Sosial dalam Pengelolaan Sumberdaya Hutan pada Masyarakat Kasepuhan, Banten Kidul," Jurnal Penelitian Sosial dan Ekonomi Kehutanan 5, no. 4 (2017): 317-335.

${ }^{6}$ Otniel Pontoh, "Identifikasi dan Analisis Modal Sosial dalam Rangka Pemberdayaan Masyarakat Nelayan Desa Gangga Dua Kabupaten Minahasa Utara," Jurnal Perikanan dan Kelautan Tropis 6, no. 3 (2010): 125-133.

${ }^{7}$ Erwin Thobias, "Pengaruh Modal Sosial terhadap Perilaku Kewirausahaan (Suatu studi pada pelaku usaha mikro kecil menengah di Kecamatan Kabaruan Kabupaten Kepulauan Talaud)," Jurnal Acta Diurna 2, no. 2 (2013), http:/ / ejournal. unsrat.ac.id/index.php/actadiurna/article/view/1412.

${ }^{8}$ Ahmadriswan Nasution et al., "Dampak Modal Sosial terhadap Kesejahteraan Rumah Tangga Perdesaan di Indonesia," MIMBAR, Jurnal Sosial dan Pembangunan 30, no. 2 (2014): 137-148.

${ }^{9}$ Slamet Widodo dan Social Capital Assessment Tool SOCAT, "Penguatan Modal Sosial untuk Pengembangan Nafkah Berkelanjutan dan Berkeadilan," in Makalah dalam Prosiding Seminar Nasional: Membangun Negara Agraris yang Berkeadilan dan Berbasis Kearifan Lokal, diselenggarakan di Fakultas Pertanian Universitas Sebelas Maret, Surakarta, vol. 19, 2012, http://www.academia.edu/download/37841156/ Penguatan_Modal_Sosial_Untuk_Pengembangan_Nafkah_Berkelanjutan_dan_ Berkeadilan.pdf.

${ }^{10}$ Djoko Susanto, “Strategi Peningkatan Kapasitas Modal Sosial dan Kualitas Sumberdaya Manusia Pendamping Pengembangan Masyarakat," Jurnal Komunikasi Pembangunan 8, no. 1 (2010), http://mail.student.ipb.ac.id/index.php/jurnalkmp/ article/view/5696. 


\section{B. Deskripsi Subjek dan Sederet Kerentanan Sosial Ekonomi}

Kota Metro yang memiliki luas wilayah $68,74 \mathrm{~km}^{2}$ pada tahun 2015 dihuni oleh lebih dari 158.415 jiwa. ${ }^{11}$ Seluruh warga Kota Metro menghasilkan sampah dalam seharinya lebih dari 10 truk. Kesemua sampah ini diproses oleh Pemerintah Kota Metro mulai dari penyapuan, pengumpulan, pengangkutan, pembuangan, hingga pengolahan.

Seluruh sampah tersebut pada akhirnya akan dibuang Tempat Pembuangan Akhir Sampah (TPAS) Karangrejo yang terletak di pinggir Kecamatan Metro Utara. TPAS Karangrejo yang mulai difungsikan sejak 2000 memiliki luas 7,9 ha dan mampu menampung sampah sampai $70.000 \mathrm{~m}^{3}$. TPAS ini merupakan satu-satunya di Kota Metro sehingga seluruh sampah Kota Metro bermuara di sini. Tidak hanya itu, posisinya yang berbatasan langsung dengan Kecamatan Pekalongan, Lampung Timur menyebabkan banyak juga warga Lampung Timur yang membuang sampah di TPAS Karangrejo.

Guna mengolah sampah, TPAS Karangrejo menggunakan sistemcurah tabur atausanitary landfill. Dengan cara ini, UPTD-TPAS Karangrejo menyiapkan area lapang, kemudian sampah dibuang di situ. Setelah itu, area tersebut ditimbun dengan tanah. Di TPAS Karangrejo terdapat empat zona yang bisa digunakan untuk setidaknya jangka waktu sepuluh tahun yang akan datang.

Dalam setiap harinya, ada 10 truk dump yang datang membawa sampah dalam tiga termin: (i) pukul 06.00-09.00 WIB sebanyak tiga rit; (ii) pukul 11.00-12.00 WIB sebanyak lima rit; dan sore hari hingga pukul 18.00 WIB sebanyak dua rit. Yang terakhir ini adalah susulan. ${ }^{12}$ Ketika truk ini membongkar sampah, puluhan pemulung segera mengerubutinya. Dalam hari biasa, setidaknya 60-100 lebih pemulung berburu rezeki di sini. Dalam konteks ini, pemulung adalahorang yang mengambil kembali benda-benda yang tidak digunakan lagi untuk didaur ulang. ${ }^{13}$

11 “Badan Pusat Statistik," diakses 21 Agustus 2017, https://metrokota.bps. go.id/linkTabelStatis/view/id/113.

${ }^{12}$ Suryanto, Wawancara, 24 November 2014.

${ }^{13}$ Lilik Hendrarini, Masalah Kesehatan Pekerja Sektor Informal Suatu Tinjauan Dari Perspektif Sosial Antropologi Kesehatan (Majalah Kesehatan Masyarakat Indonesia, Tahun XXIV, 1996). 
Mayoritas pemulung tinggal di sekitar TPAS di kelurahan Karangrejo dan desa Kalibening, Pekalongan selain dari Batanghari, Lampung Timur.Jumlah pemulung ini bersifat fluktuatif karena beberapa faktor, di antaranya adalah (i) ada di antaranya yang menjadikan profesi pemulung hanya sebagai sambilan. Sehingga ia hanya akan memulung pada hari-hari tertentu. Ada juga yang juga berprofesi sebagai buruh tani atau petani penggarap. Sehingga ketika musim tanam atau panen, mereka akan absen dari aktivitas memulung.

Mayoritas pemulung adalah perempuan. Dalam konteks ini, perempuan sangat rentan karena ia terkena beban ganda selain beban kerja domestik, mulai dari mengurus anak, memasak, mencuci, dan mengurus rumah. Tidak jarang, mereka harus mengajak anak untuk turut serta memulung sampah. Hal ini tentu sangat berbahaya bagi kesehatan anak.

Mayoritas pemulung berada tepat atau bahkan di bawah garis kemiskinan. Tidak adanya pekerjaan lain yang lebih menjanjingan secara finansial membuat $29 \%$ pemulung menjalani profesinya. Sedangkan nyaris $52 \%$ pemulung membantu suaminya. Ini artinya, suami mereka bekerja pada sektor nonformal yang penghasilannya belum cukup untuk memenuhi kebutuhan harian mereka.

Dilihat dari tingkat pendidikan, mayoritas pemulung hanya menuntaskan pendidikan pada tingkat SD. Ini artinya, mereka lemah dalam akses terhadap pendidikan.

Kemudian dilihat dari penghasilan, rata-rata setiap pemulung mendapatkan penghasilan sebanyak Rp 10.000 s/d Rp 20.000 per hari. Penghasilan ini jauh di bawah Upah Minimum Regional Kota Metro yang saat observasi lapangan ini dilakukan sebesar Rp 855.000.

Di sisi lain, pemulung tadi dapat dikelompokkan ke dalam dua jenis: peulung lepas dan pemulung kontrak. Pemulung lepas bekerja secara mandiri. Ia berhak bekerja kapan pun ia mau dan bisa menjual pulungannya kepada pengepul mana pun yang ia kehendaki. Hal ini berbeda dengan pemulung kontrak yang tergantung pada bandar yang meminjamkan uang kepada mereka. Pemulung ini diwajibkan setor sampah ke bandar dan bandar akan memotong uang pembelian sampah tadi untuk melunasi hutangnya. Bisa dibilang, bandar ini 
adalah rentenir yang mencekik pemulung. Tidak hanya mewajibkan menjual barang, bandar juga memotong uang sekaligus memotong timbangan sesukanya.

Kemudian, saat observasi awal dilakukan, seluruh pemulung bekerja secara sendiri-sendiri. Mereka belum memiliki serikat atau paguyuban sesama pemulung yang bisa digunakan sebagai media akumulasi dan konsolidasi kapital sosial. Padahal, sejatinya mereka sudah memiliki potensi modal tersebut dengan banyaknya intensitas bertemu dalam keseharian. Sayangnya, modal potensial ini tertutup dan tergerus oleh persaingan antar pemulung dalam berebut sampah.

Dengan demikian, bisa disimpulkan beberapa aspek kerentanan sosial ekonomi pemulung di TPAS Karangrejo Kota Metro sebagai berikut: (a) Belum diakuinya harkat dan martabat pemulung sebagai 'pahlawan kebersihan', dan bagian dari usaha perbaikan kesehatan lingkungan dan pembangunan ekonomi; (b) Mereka miskin, dengan penghasilan yang minim, sekitar Rp. 10.000 ,- s/d Rp. 20.000,- aatau Rp. 600.000,- per bln, pendapatan ini masih jauh dibawah UMR Kota Metro Rp. 855.000,-; (c) Pelayanan sosial, kesehatan belum diperoleh, tidak memiliki stimulan permodalan untuk memicu pertumbuhan ekonomi keluarga; (d) Rentan tertular virus/penyakit, kurang memperhatikan kesehatan dan keselamatan kerja, bekerja tanpa pelindung keselamatan yg memadai; (e) Pendidikan pemulung, istri, anak rendah; sehingga wawasan kurang, motivasi kurang untuk beralih ke profesi lain; (f) Peran bandar (pengepul) sangat dominan, pemulung belum memiliki kelembagaan usaha, sosial sebagai naungan para pemulung

\section{Tahapan Konsolidasi Kapital Sosial Pemulung Sampah TPAS Karangrejo}

Keadaan para warga pemulung yang masih bekerja secara individu perlu direspon dengan tepat agar mereka dapat bekerja sama sehingga sosial kapital yang ada pun dapat dikembangkan sebagai upaya pemberdayaan warga pemulung yang bertaraf hidup 
lebih baik. ${ }^{14}$ Oleh karena itu konsolidasi kepada warga pemulung pun kemudian dilakukan oleh Tim Pengabdian IAIN Metro dengan juga melibatkan beberapa stakeholder yang lain seperti WALHI (Wahana Lingkungan Hidup Indonesia) kota Metro, UPTD-TPAS Karangrejo, Pamong desa, RT dan tokoh masyarakat.Konsolidasi sosial kapital, sebagaimana dijelaskan oleh Harris, mampu membentuk konstruksi kehidupan bermasyarakat (civil society) yang lebih baik. ${ }^{15}$ Konsolidasi yang dilakukan berbasis kelompok untuk merealisasikan adanya sebuah organisasi atau kelompok warga pemulung.

Adapun beberapa tahap yang dilakukan untuk membentuk sebuah kelompok atau paguyuban warga pemulung adalah sebabagai berikut:

\section{Tahap Penyadaran (Awareness Building)}

Ini adalah penjajakan awal ke lokasi penelitian, yang dilakukan adalah penelusuran wilayah TPAS Karangrejo, pemetaan awal, dan menemukan key person untuk menggali informasi awal sebanyak mungkin untuk perencanaan dampingan/penelitian. Pada tahap ini dilakukan membangun kepercayaan pemulung, dilakukan melalui proses dialog informal dari rumah ke rumah dan ke tokoh pemulung yang ada di sekitar TPAS Karangrejo, targetnya adalah warga dapat mengenal tim peneliti sambil menggali informasi awal sebanyak-banyaknya. Berkunjung ke rumah pemulung merupakan salah satu cara Tim peneliti membangun kedekatan, jika kedekatan terjalin maka proses komunikasi selanjutnya menjadi lebih efektif.

Untuk kemudian setelah terbangun kepercayaan secara perlahan mulai diajak diskusi tentang bagaimana merubah keadaan komunitas pelumung menjadi lebih baik lagi. Dari kegiatan awal ini tim peneliti memiliki gambaran awal keadaan komunitas pemulung, baik secara sosial dan ekonomi, serta diperoleh gambaran mengenai struktur lokasi tempat pembuangan sampah. Pada kegiatan awal ini juga mulai dibangun komunikasi awal dengan pengelola UPTD

${ }^{14}$ Jeffrey L. Jordan, Bulent Anil, dan Abdul Munasib, “Community Development and Local Social Capital," Journal of Agricultural and Applied Economics 42, no. 1 (2010): 143-159.

${ }^{15}$ John Harriss, "Social Capital Construction and the Consolidation of Civil Society in Rural Areas," WP. No. 00-16. Destin. LSE. Nov, 2001, 1-16, http://www.lse. ac.uk/internationalDevelopment/pdf/WP/WP16.pdf. 
TPAS Karangrejo mengenai kegiatan pemberdayaan pemulung yang akan dilakukan.

\section{Tahap Analisa Kebutuhan (Need Assessment)}

Proses pemberdayaan akan berjalan efektif apabila proses pemberdayaan itu dilakukan sesuai dengan kebutuhan mendasar komunitas yang didampingi. Oleh karena itu proses pengidentifikasian kebutuhan komunitas menjadi point penting dalam proses pemberdayaan yang akan dilakukan. ${ }^{16}$

Proses identifikasi kebutuhan dilakukan dalam beragam kegiatan, seperti melalui dialog, kunjungan ke rumah, kunjungan ke tempat pemulung bekerja, dan dialog dengan pengelola UPTD TPAS Karangrejo.Profil demografi pemulung yang 58\% merupakan perempuan juga turut mempengaruhi jenis program dan kegiatan yang akan dilakukan. Sebagian besar mereka berkerja karena kebutuhan ekonomi yang kurang, sehingga terpaksa berkerja membantu suami dalam mendapatkan penghasilan tambahan.

Beberapa kebutuhan yang berhasil diidentifikasi berdasarkan keterangan para pemulung dan tokoh masyarakat adalah antara lain: (a) Pemasukan harian yang lebih besar; (b) Pembagian area pemulungan antara pemulung muda dan pemulung lanjut usia; (c) Adanya lapak sampah yang berjarak dekat dengan lokasi TPAS; (d) Adanya koperasi simpan pinjam berbunga rendah

\section{Tahap Pendampingan berkelanjutan (Consistent Assistance)}

Salah satu tantangan setelah terbentuknya organisasi kemasyarakatan, termasuk paguyuban ini adalah bagaimana seluruh anggota paguyuban ini dapat berperan aktif dan berkontribusi untuk kemajuan paguyuban. Oleh karena itu, pendampingan pun terus dilakukan. Peneliti menyadari bahwa pengalaman dan tingkat pendidikan yang rendah para anggota paguyuban menjadikan mereka kurang percaya diri apabila setelah berdirinya paguyuban mereka tidak didampingi.

${ }^{16}$ Anu Kasmel dan Pernille Tanggaard, "Conceptualizing Organizational Domains of Community Empowerment through Empowerment Evaluation in Estonian Communities," Societies 1, no. 1 (2011): 3-29. 
Merespon hal ini, beberapa program diagendakan untuk mengawal berjalannya paguyuban pemulung ini. Adapun beberapa cara yang dilakukan oleh tim pengabdian IAIN Metro adalah sebagai berikut: (a) Melakukan kunjungan dan dialog bersama warga pemulung secara berkala untuk mengetahui masalah-masalah yang dihadapi dan kemudian berupaya mencarikan solusi; (b) Memberikan pelatihan atau workshop untuk meningkatkan keterampilan anggota paguyuban khususnya dalam mengolah sampah agar menjadi bernilai lebih tinggi.; (c) Mengundang ahli administrasi keuangan untuk memberikan bimbingan dan pelatihan pengurus paguyuban; (d) Membentuk regenerasi tim yang dapat membantu pendampingan paguyuban.

\section{Pengejawantahan Konsolidasi Kapital Sosial}

\section{Pendirian Paguyuban Pemulung (Organization Establishment)}

Untuk mewadahi aspirasi warga sekaligus menciptakan suasana kebersamaan dan kerjasama yang berkesinambungan serta usaha bersama yang lebih maju, ${ }_{17}^{17}$ aka sebuah organisasi didirikan. Setelah dilakukan proses pendekatan sambil membangun kesadaran, tahap berikutnya adalah membangun perangkat organisasi kumunitas. Tahap ini merupakan bagian tersulit dari proses pemberdayaan yang tim peneliti lakukan. Resistensi dan sikap acuh pada awal proses terasa sekali pada saat tim peneliti menyampaikan wawasan dan gagasan mengenai kelompok usaha bersama (KUBE).

Gagasan pembentukan kelompok usaha bersama ini disampaikan ke tokoh-tokoh pemulung secara terbatas terlebih dahulu, agar terbangun pemahaman awal yang baik, baru kemudian setelah para tokoh kunci bisa memahami proses berikutnya adalah membawa gagasan ini ke tingkat kelompok. Setelah berdiskusi dengan para stakeholder dan warga pemulung maka terbentuklah paguyuban yang diberi nama Harapan Makmur. Adapun pengurus inti paguyuban Harapan Makmur adalah Bpk. Suryanto (Ketua), Bpk. Muhammad Zen (Sekretaris), dan Ibu Siti Zanah (Bendahara).

${ }^{17}$ Bridget M. Hutter dan Joan O'Mahony, The Role of Civil Society Organisations in Regulating Business (Centre for the Analysis of Risk and Regulation, London School of Economics and Political Science, 2009), 1-17, http://www.lse.ac.uk/accounting/ CARR/pdf/DPs/Disspaper26.pdf. 
Respon yang muncul dari gagasan ini adalah pemulung berfikir apa manfaat kelompok usaha bersama ini, kemudian sumber dananya dari mana, dan administrasinya bagaimana. Pertanyaanpertanyaan itu kerap muncul dalam sesi dialog atau percakapan informal tim peneliti dengan para pemulung. Mereka merasa tidak akan mampu membuat dan mengelola kelompok usaha bersama, karena merasa sudah nyaman dengan cara memulung yang selama mereka lakukan.

Dengan memiliki lapak sampah sendiri, para anggota paguyuban memiliki rasa memiliki terhadap organisasi mereka (sense of belonging) sehingga setiap mereka mendapatkan sampah di PTAS, mereka akan menjualnya ke paguyuban mereka, tidak ke paguyuban yang lain. Hal ini dimaksudkan agar paguyuban dapat terus hidup dan membangun hubungan yang lebih saling menguntungkan antar anggota.

Alur pengelolaan sampah adalah: 1) Sampah sampai di TPAS Karangrejo, kemudian 2) para pemulung memungut sampah di TPAS, lalu 3) para pemulung menjual hasil sampahnya ke Lapak paguyuban; setelah itu 4) paguyuban menjual ke pengepul sampah yang lebih besar dan 5) hasil penjualan akan digunakan untuk membeli sampah dari anggota dan pemulung lain serta untuk operasional paguyuban. Sisa hasil usaha (SHU) penjualan sampah akan diberikan ke seluruh anggota paguyuban pada bulan Ramadhan.

Salah satu keberhasilan paguyuban adalah mampu menyediakan lapak sampah yang memberikan harga bersaing. Satu hal yang lebih penting adalah sistem "ada barang ada uang" dalam arti setiap pemulung selesai menimbang sampah yang mereka dapatkan, mereka dapat langsung mendapatkan uangnya, tidak menunggu atau menunggak dalam jangka waktu tertentu. Hal ini sangat bermanfaat karena warga pemulung sangat membutuhkan pemasukan harian.

\section{Pembentukan Koperasi Simpan Pinjam (KSP)}

Warga pemulung di Karangrejo merupakan warga yang sebagian besar berpenghasilan kecil dan oleh sebab itu, seringkali ketika ada kebutuhan besar yang cukup mendadak, mereka seringkali meminjam uang dari rentenir. Sayangnya untuk mengembalikan 
uang yang mereka pinjam, pihak rentenir meminta bunga pinjaman yang cukup besar (5-10\%) sehingga memberatkan para warga.

Untuk merespon hal ini, tim pengabdian membentuk koperasi simpan pinjam yang dikhususkan untuk warga pemulung yang telah menjadi anggota paguyuban Harapan Makmur. Dana stimulan yang digunakan sebagai modal awal koperasi adalah dana yang berasal dari donatur khusunya BMT Fajar Metro. Layanan yang diberikan adalah layanan penimpanan dan pinjaman dana untuk anggota paguyuban. Untuk dapat meminjam dana di koperasi ini, pengurus koperasi mensyaratkan simpanan wajib sebesar $5 \mathrm{~kg}$ sampah. Keterbatasan dana membuat pengurus hanya dapat memberikan pinjaman dana maksimal 300 ribu per anggota. Antusiasme warga sangat tinggi terhadap koperasi ini, ditandai dengan cepatnya dana stimulan ini digulirkan.

Konsekuensi dari pendirian koperasi ini adalah harus ada tenaga yang memiliki kemampuan administratif yang baik. Menyadari koperasi simpan pinjam membutuhkan keterampilan administratif yang baik, tim pengabdian mengundang dosen mata kuliah ekonomi yang dapat memberikan pembekalan dan pelatihan dasar untuk pengurus koperasi ini tentang bagaimana cara menghitung dan mengadministrasikan jalannya aktivitas koperasi.

\section{E. Pengembangan Konsolidasi Kapital Sosial}

Pekerjaan rumah besar yang kemudian harus mendapat perhatian khusus adalah bagaimana caranya warga pemulung memiliki kemampuan untuk mengolah sampah yang lebih berkualitas sehingga dapat meningkatkan nilai jual dari produk sampah yang dihasilkan. Pengelolaan sampah (Waste Management) rumah tangga yang baik dan inovatif dapat meningkatkan nilai ekonomis dan kemudian meningkatkan taraf hidup masyarakat. ${ }^{18}$ Adapun upaya-upaya yang dilakukan untuk meningkatkan kesadaran dan keterampilan mengolah sampah adalah sebagai berikut:

${ }^{18}$ Amornchai Challcharoenwattana dan Chanathip Pharino, “Co-benefits of Household Waste Recycling for Local Community's Sustainable Waste Management in Thailand," Sustainability 7, no. 6 (2015): 7417-7437. 


\section{Kunjungan ke usaha bank sampah yang ada}

Salah satu bentuk kegiatan untuk memperkuat kapasitas kelompok melakukan kunjungan, dan observasi ke kelompok usaha bersama yang telah ada. Tim mengajak pengurus paguyuban untuk bersama-sama melihat langsung cara kerja pengelolaan sampah. Kunjugan ini bertujuan untuk lebih meningkatkan motivasi, dan memberikan gambaran lebih jelas bagaimana cara mengelola kelompok usaha bersama. Salah satu tempat yang dikunjungi adalah kegiatan swadaya masyarakat di Desa Punggus Lampung Tengah dalam mengelola Bank Sampah, serta unit pengolahan bijih plastik berbahan rongsokan botol dan gelas plastik yang ada di Kecamatan Metro Selatan.

\section{Workshop Capacity Building}

Warga pemulung jarang sekali mendapatkan pelatihanpelatihan yang dapat meningkatkan keterampilan mereka. Untuk itu, perlu dilakukan kegiatan capacity building secara berkala dan dengan tema yang berbeda. Kegiatan ini dimaksudkan untuk mendorong komunitas memiliki kapasitas untuk mengembangkan diri secara mandiri dan untuk efektifitas organisasi. ${ }^{19}$ Sebagai organisasi baru, Paguyuban Harapan Makmur punya banyak agenda dan rencana untuk melakukan proses pemberdayaan sesuai kebutuhan komunitas. Beberapa pelatihan yang telah dilaksanakan adalah pelatihan teknik pembuatan pupuk cair, pupuk kompos, dan biogas berbahan sampah.

Selain itu, juga telah dilaksanakan workshop pengolahan sampah kertas melalui produksi bubur kertas (pulp). Kegiatan ini mengajarkan para warga pemulung yang kebanyakan kaum ibu-ibu untk belajar mengolah sampah kertas yang harganya hanya sekitar 2000 per kg menjadi produk kertas daur ulang seperti kertas undangan elegan yang dapat bernilai sekitar 2000-5000 per lembarnya.

${ }^{19}$ Give Volunteer Act, "Capacity Building for Organizational Effectiveness," 2011, http://www.calgaryunitedway.org/images/uwca/our-work/supportingnon-profits/capacity-building/capacity \%20building\%20for\%20organizational $\% 20$ effectiveness.pdf. 


\section{Pendampingan Pengajuan Alat Pengolah Sampah Plastik}

Selain keterampilan mengolah sampah yang baik, cara lain untuk meningkatkan nilai ekonomis dari sampah adalah dengan tersedianya alat atau mesin pengolah sampah. Melihat ketersediaan sampah plastik mendominasi suply sampah yang terkumpul di paguyuban, para pengurus menyampaikan kepada tim tentang keinginan mereka memiliki mesin penghancur atau perajang plastik. Fungsi mesin tersebut digunakan untuk menghancurkan, merajang maupun menggiling sampah plastik menjadi bentuk ukuran kecil atau dikenal dengan sebutan biji plastik. Penggunaan mesin perajang limbah plastik memiliki peranan penting untuk menjaga kebersihan lingkungan akibat sampah plastik yang sulit untuk diuraikan atau di hancurkan.

Mengingat tidak adanya dana untuk membeli mesin yang cukup mahal ini, tim pengabdian menghubungi pihak WALHI (Warga Lingkungan Hidup) agar dapat memberikan hibah mesin ini kepada warga pemulung paguyuban Harapan Makmur. Setelah melakukan audiensi pihak Walhi akhirnya memutuskan untuk menjadikan paguyuban ini prioritas penerima hibah mesin perajang plastik untuk tahun anggaran 2018.

\section{F. Mengukur Tingkat Keberdayaan Pemulung Sampah TPAS Karangrejo}

Aktivitas paguyuban pemulung Karangrejo yang pada intinya adalah jual beli sampah ternyata memberikan dampak positif di berbagai aspek, tidak hanya aspek ekonomis tetapi juga aspek relasi sosial dan keagamaan.

\section{Aspek ekonomi}

Kedisiplinan pihak paguyuban untuk langsung membayar semua sampah yang dijual oleh pemulung memberikan semangat tersendiri bagi mereka untuk bekerja mencari sampah secara lebih giat. Efek positifnya adalah yang awalnya rata-rata penghasilan mereka sekitar 10.000-20.000 per hari menjadi 15.000-30.000 perhari. Selain itu, setiap hari terdapat 6-8 pekerja yang membantu membersihkan dan memilah sampah. Sebagian mereka sebelumnya hanya ibu rumah 
tangga yang tidak bekerja. Sekarang mereka memiliki penghasilan kurang lebih 20.000 per hari.

Mbah Diyem, sebagai contoh, sebelum menjadi pekerja tetap di paguyuban, dengan kondisi fisik yang sudah lemah ia memulung sampah di TPAS dan harus bersaing denga pemulung lain yang fisknya lebih kuat. Akibatnya ia tidak dapat bekerja dengan cepat dan mendapatkan sampah yang sedikit. Sekarang sudah lebih dari 1 tahun ia bekerja di paguyuban, tidak perlu bekerja terlalu keras dengan ikut berebut sampah di TPAS.

\section{Relasi sosial yang multikultural}

Warga pemulung di Karangrejo merupakan masyarakat multikultural yang terdiri dari berbagai latar belakang suku, seperti Jawa, Lampung, Sunda dan lai-lain. Di banyak tempat seringkali terjadi kesenjangan antar suku yang mengakibatkan relasi sosial mereka kurang baik dan akhirnya menyulut adanya konflik. Lampung merupakan salah satu provinsi dengan jumlah konflik terbanyak di Indonesia. ${ }^{20}$ Aktivitas paguyuban pemulung di Karangrejo ini, sedikit banyak telah menyumbangkan sebuah model interaksi sosial yang dapat mengarah kepada pencegahan konflik (conflict prevention).

Interaksi sosial yang terjadi di kalangan warga pemulung di dalam paguyuban ternyata memberikan dampak positif tehadap tumbuhnya rasa saling memahami (mutual understanding) antar warga meski mereka berbeda latar belakang suku dan budaya. ${ }^{21} \mathrm{Hal}$ ini tentunya sangat baik untuk menekan kemungkinan terjadinya konflik horizontal dan meningkatkan pembanguanan perdamaian (peace building) di kalangan grassroot.

\section{Filantropi Islam}

Aspek positif lain yang dapat dijadikan indikator perkembangan pemberdayaan masyarakat pemulung Karangrejo adalah adanya filantropi. Kegiatan ini bertujuan untuk amal

${ }^{20}$ Leydi Silvana, "Pemetaan Daerah Rawan Konflik di Provinsi Lampung," Jurnal Bina Praja: Journal of Home Affairs Governance 5, no. 3 (2013): 169-175. $45-57$.

${ }^{21}$ Kevin Avruch, "Cross-Cultural Conflict," Conflict Resolution 1 (2009): 
paguyuban sekaligus, apabila mengacu dalam dunia bisnis, ${ }^{22}$ sebagai wahana mengenalkan paguyuban kepada pihak luar. Kegiatan ini dilaksanakan dalam bentuk program pembagian sembago gratis baik bagi anggota paguyuban maupun warga yang bukan anggota paguyuban. Kegiatan ini dilaksanakan di akhir bulan Ramadhan sebagai bekal tambahan warga menyambut hari raya Idul Fitri. Kegiatan ini sudah dilaksanakan dua kali semenjak berdiri pada tahun 2014. Tahun ini penerima bantuan sembako adalah 60 orang.

Ketua paguyuban, Mugiyanto, menyatakan bahwa kegiatan ini dilaksanakan untuk mendekatkan peran paguyuban tidak hanya bagi anggota tetapi juga bagi warga sekitar. Dana yang digunakan didapatkan dari tabungan pendapatan yan disisihkan setiap bulannya. Kategori penerima bantuan sembako ini adalah: 1) warga pemulung yang menjadi anggota, 2) pemulung yang bukan anggota tetapi menjual sampahnya ke paguyuban, 3) warga sekitar lapak yang kemungkinan terkena bau sampah dan 4) para Selain pembagian sembako di bulan Ramadhan, pengurus paguyuban juga memberikan bantuan, meskipun tidak banyak, bagi anggota paguyuban yang sakit.

\section{G. Peluang dan Tantangan}

Setelah melakukan pendampingan terhadap warga pemulung di paguyuban Harapan Makmur, terdapat beberapa peluang dan tantangan yang dihadapi oleh warga dan tim. Adapun peluangpeluang yang dapat dijadikan dasar perkembangan pemberdayaan warga pemulung antara lain:

\section{Ketersediaan Produk}

Produk yang dikelola oleh warga pemulung adalah sampah yang mana produk ini tidak akan pernah habis sehingga mereka tidak perlu khawatir kehabisan produk. Selain itu, jarak TPAS yang dekat membuat pemulung lebih mudah menjangkau tempat ini tanpa memakan banyak waktu.

${ }^{22}$ Philip L. Fioravante, "Corporate Philanthropy: A Strategic Marketing Consideration," The Journal of Applied Business and Economics 11, no. 3 (2010): 1-6. 


\section{Adanya pasar}

Ketersediaan pasar atau dalam hal ini pengepul sampah yang lebih besar adalah sebuah keniscayaan yang harus ada untuk terus melanjutkan usaha para warga pemulung ini. Pengurus paguyuban sendiri tidak kesulitan untuk "membuang" hasil pembelian sampah dari para pemulung. Hubungan yang saling tergantung dan saling menguntungkan ini menjadikan usaha di bidang sampah ini akan terus berlanjut selama dikelola dengan baik.

\section{Terbentuknya Paguyuban Pemulung}

Berdirinya paguyuban pemulung Harapan Makmur menjadi wadah tersendiri bagi para pemulung yang menjadi anggotanya. Pasalnya, mereka tidak hanya dapat menjual sampah tetapi juga dapat mengajukan pinjaman dana ke koperasi simpan pinjam yang juga telah didirikan. Paguyuban ini juga telah merangsang tumbuhnya budaya baru bahwa dengan bekerja sama, para pemulung akan mendapatkan keuntungan yang lebih banyak dari sekedar bekerja sendiri-sendiri.

Sementara itu, beberapa tantangan yang dihadapi pemulung sampah di TPAS Karangrejo ada tiga hal: lemahnya administrasi, minimnya nilai tambah yang diberikan pada produk, dan minimnya pangsa pasar.

\section{Administrasi yang lemah}

Mayoritas pemulung sampah di TPAS Karangrejo memiliki pendidikan hanya sampai Sekolah Dasar atau Sekolah Rakyat. Rendahnya taraf pendidikan ini menyebabkan rendahnya kesadaran akan pentingnya tertib administrasi. Hal ini juga berimbas pada masyarakat yang belum memiliki pengetahuan dan skill dalam menerapkan tertib administrasi. Karena kondisi ini, seringkali pihak pengurus paguyuban kesulitan menentukan jumlah keuntungan yang mereka dapatkan per hari, per minggu atau per bulannya; padahal mereka yakin bahwa mereka mendapatkan keuntungan.

\section{Rendahnya Nilai Tambah}

Yang dilakukan para pemulung selama ini hanya memilah sampah berdasarkan jenisnya lalu membersihkannya. Tidak ada upaya lebih lanjut untuk meningkatkan nilai tambah dari produk tersebut. Hal ini bukan karena mereka tidak diberi pelatihan, namun mereka 
masih memiliki mindset "mendapatkan barang hari ini, menjual hari ini dan mendapatkan uang hari ini". Paradigma ini menmbulkan rasa malas untuk mengolah produk sampah yang tidak langsung dapat dijual pada hari itu juga.

\section{Harga Sampah yang tidak Menentu}

Pemulung tidak pernah dapat memastikan kapan harga naik dan kapan harga turun. Sejauh ini mereka hanya dapat melakukan prediksi bahwa sat mendekati lebaran maka harga sampah turun padahal saat itulah banyak sampah melimpah. Belum ada upaya konkrit dari pemerintah untuk mengatur harga sampah. Semua masih sangat tergantung kepada pengepul besar.

\section{H. Simpulan}

Upaya-upaya konkrit pihak perguruan tinggi khususnya perguruan tinggi keIslaman harus terus dilakukan agar para akademisi yang sering dikenal dengan kaum "berilmu" ini tidak menjadi menara gading yang seolah tidak dapat dirasakan kebermanfaatannya di kalangan grassroot di sekitar mereka. Pendampingan berkelanjutan yang dilakukan dosen tim pengabdian IAIN Metro ini merupakan, meskipun belum sepenuhnya berjasil, salah satu contoh riil dari upaya ini.

Isu-isu lingkungan yang terus mendunia menjadi alasan tersendiri untuk menjadikan pendampingan terhadap para pemulung ini salah satu prioritas. Di kota Metro, yang merupakan kiblat pendidikan di provinsi Lampung, permasalahan sampah masih menjadi pekerjaan rumah bagi pemerintah dan warganya. Oleh karena itu, terlepas tantangan yag tidak mudah, konsentrasi terhadap pengelolaan sampah dan semua pihak yag terkait, khususnya pemulung, harus terus dilakukan dengan terus memaksimalkan peluang-peluang yang ada[.] 


\section{REFERENSI}

Act, Give Volunteer. "Capacity Building for Organizational Effectiveness," 2011. http://www.calgaryunitedway.org/ images/uwca/our-work/supporting-non-profits/capacitybuilding/capacity $\%$ 20building $\% 20$ for $\% 20$ organizational $\% 20$ effectiveness.pdf.

Avruch, Kevin. "Cross-Cultural Conflict." Conflict Resolution 1 (2009): 45-57.

“Badan Pusat Statistik." Diakses 21 Agustus 2017. https:/ / metrokota. bps.go.id/linkTabelStatis/view/id/113.

Bourdieu, Pierre. "The Forms of Capital," 1986. https://www. marxists.org/reference/subject/philosophy/works/fr/ bourdieu-forms-capital.htm\#n11.

Challcharoenwattana, Amornchai, dan Chanathip Pharino. "Cobenefits of Household Waste Recycling for Local Community's Sustainable Waste Management in Thailand." Sustainability 7, no. 6 (2015): 7417-7437.

Fioravante, Philip L. “Corporate Philanthropy: A Strategic Marketing Consideration." The Journal of Applied Business and Economics 11, no. 3 (2010): 91.

Harriss, John. "Social Capital Construction and the Consolidation of Civil Society in Rural Areas." WP. No. 00-16. Destin. LSE. Nov, 2001. http://www.lse.ac.uk/internationalDevelopment/pdf/ WP/WP16.pdf.

Hendrarini, Lilik. Masalah Kesehatan Pekerja Sektor Informal Suatu Tinjauan Dari Perspektif Sosial Antropologi Kesehatan. Majalah Kesehatan Masyarakat Indonesia, Tahun XXIV, 1996.

Hutter, Bridget M., dan Joan O'Mahony. The Role of Civil Society Organisations in Regulating Business. Centre for the Analysis of Risk and Regulation, London School of Economics and Political Science, 2009. http://www.lse.ac.uk/accounting/CARR/pdf/ DPs/Disspaper26.pdf.

Jordan, Jeffrey L., Bulent Anil, dan Abdul Munasib. “Community Development and Local Social Capital." Journal of Agricultural and Applied Economics 42, no. 1 (2010): 143-159. 
Kasmel, Anu, dan Pernille Tanggaard. "Conceptualizing Organizational Domains of Community Empowerment through Empowerment Evaluation in Estonian Communities." Societies 1, no. 1 (2011): 3-29.

Nasution, Ahmadriswan, Ernan Rustiadi, Bambang Juanda, dan Setia Hadi. “Dampak Modal Sosial terhadap Kesejahteraan Rumah Tangga Perdesaan di Indonesia." MIMBAR, Jurnal Sosial dan Pembangunan 30, no. 2 (2014): 137-148.

Pontoh, Otniel. "Identifikasi dan Analisis Modal Sosial dalam Rangka Pemberdayaan Masyarakat Nelayan Desa Gangga Dua Kabupaten Minahasa Utara." Jurnal Perikanan dan Kelautan Tropis 6, no. 3 (2010): 125-133.

Portes, Alejandro. "Social Capital: Its Origins and Applications in Modern Sociology.” Annual review of sociology 24, no. 1 (1998): $1-24$.

Pranadji, Tri. "Penguatan Modal Sosial Untuk Pemberdayaan Masyarakat Pedesaan dalam Pengelolaan Agroekosistem Lahan Kering (Studi Kasus di Desa-desa (Hulu DAS) Ex Proyek Bangun Desa, Kabupaten Gunungkidul dan Ex Proyek Pertanian Lahan Kering, Kabupaten Boyolali)." Jurnal Agro Ekonomi 24, no. 2 (2016): 178-206.

Silvana, Leydi. "Pemetaan Daerah Rawan Konflik di Provinsi Lampung." Jurnal Bina Praja: Journal of Home Affairs Governance 5, no. 3 (2013): 169-175.

Suharjito, Didik, dan Gunanto Eko Saputro. "Modal Sosial dalam Pengelolaan Sumberdaya Hutan pada Masyarakat Kasepuhan, Banten Kidul." Jurnal Penelitian Sosial dan Ekonomi Kehutanan 5, no. 4 (2017): 317-335.

Suryanto. Wawancara, 24 November 2014.

Susanto, Djoko. "Strategi Peningkatan Kapasitas Modal Sosial dan Kualitas Sumberdaya Manusia Pendamping Pengembangan Masyarakat." Jurnal Komunikasi Pembangunan 8, no. 1 (2010). http://mail.student.ipb.ac.id/index.php/jurnalkmp/article/ view/5696. 
Syahra, Rusydi. "Modal Sosial: Konsep dan Aplikasi." Jurnal Masyarakat dan Budaya 5, no. 1 (2003): 1-22.

Thobias, Erwin. "Pengaruh Modal Sosial terhadap Perilaku Kewirausahaan (Suatu studi pada pelaku usaha mikro kecil menengah di Kecamatan Kabaruan Kabupaten Kepulauan Talaud)." Jurnal Acta Diurna 2, no. 2 (2013). http://ejournal. unsrat.ac.id/index.php/actadiurna/article/view/1412.

Widodo, Slamet, dan Social Capital Assessment Tool SOCAT. "Penguatan Modal Sosial untuk Pengembangan Nafkah Berkelanjutan dan Berkeadilan." In Makalah dalam Prosiding Seminar Nasional: Membangun Negara Agraris yang Berkeadilan dan Berbasis Kearifan Lokal, diselenggarakan di Fakultas Pertanian Universitas Sebelas Maret, Surakarta, Vol. 19, 2012. http:/ / www. academia.edu/download/37841156/Penguatan_Modal_ Sosial_Untuk_Pengembangan_Nafkah_Berkelanjutan_dan_ Berkeadilan.pdf. 
